University of Rhode Island

DigitalCommons@URI

Open Access Master's Theses

1987

\title{
HUNT RIVER GROUNDWATER PROTECTION: ANALYSIS AND RECOMMENDATIONS
}

Roland M. Deblois

University of Rhode Island

Follow this and additional works at: https://digitalcommons.uri.edu/theses

\section{Recommended Citation}

Deblois, Roland M., "HUNT RIVER GROUNDWATER PROTECTION: ANALYSIS AND RECOMMENDATIONS" (1987). Open Access Master's Theses. Paper 510.

https://digitalcommons.uri.edu/theses/510

This Thesis is brought to you for free and open access by DigitalCommons@URI. It has been accepted for inclusion in Open Access Master's Theses by an authorized administrator of DigitalCommons@URI. For more information, please contact digitalcommons-group@uri.edu. 
HUNT RIVER GROUNDWATER PROTECTION:

ANALYSIS AND RECOMMENDATIONS

BY

ROLAND M. DEBLOIS

A RESEARCH PROJECT SUBMITTED IN

PARTIAL FULFILLMENT OF THE REQUIREMENTS

FOR THE DEGREE AND MASTER OF

COMMUNITY PLANNING

UNIVERSITY OF RHODE ISLAND

1987 
MASTER OF COMMUNITY PLANNING

RESEARCH PROJECT

OF

ROLAND M. DEBLOIS

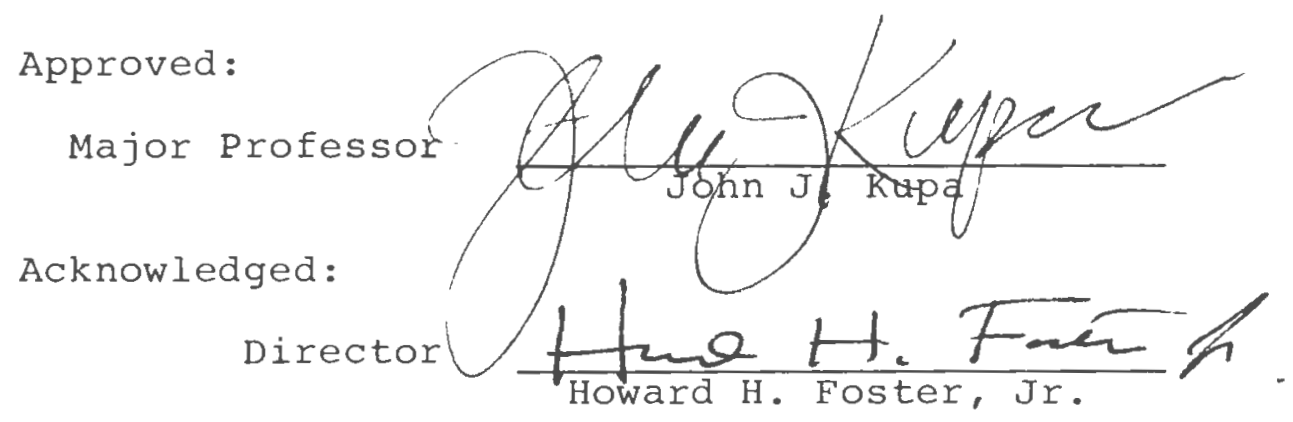




\section{ABSTRACT}

The Hunt River, which forms a natural boundary between the towns of East Greenwich and North Kingstown, is directly associated with an extensive groundwater reservoir; the reservoir is an important source of present and future drinking water supplies. Due to the direct effect that land use has on groundwater quality, legislation is needed to ensure that land uses are regulated to protect potable groundwater supplies. While legislation presently exists on the federal and state level to combat drinking water pollutants, local municipalities are in a position to have more site-specific regulatory influence through the establishment of aquifer recharge overlay districts. Within the overlay districts, land use can be regulated to ensure that the potential for aquifer pollution is minimized. This report focuses on the characteristics of the Hunt River aquifer and its primary recharge area; a model Hunt River Aquifer Protection Ordinance is presented to be considered in whole or part for adoption by the towns of East Greenwich and/or North Kingstown. 


\section{ACKNOWLEDGEMENTS}

Thanks go out to my advising professor Dr. John J. Kupa, and to the faculty and students of the U.R.I. Graduate Program of Community Planning (1983-1985) who have contributed to my graduate education and overall well-being. East Greenwich Town Planner Richard C. Youngken was also very helpful in taking the time to review and critique the workings of this research project. special thanks to my parents, sue, and a dog named "Thesis" for their loving support and persistence in prompting me to complete this final project for my Master of Community Planning degree. 


\section{TABLE OF CONTENTS}

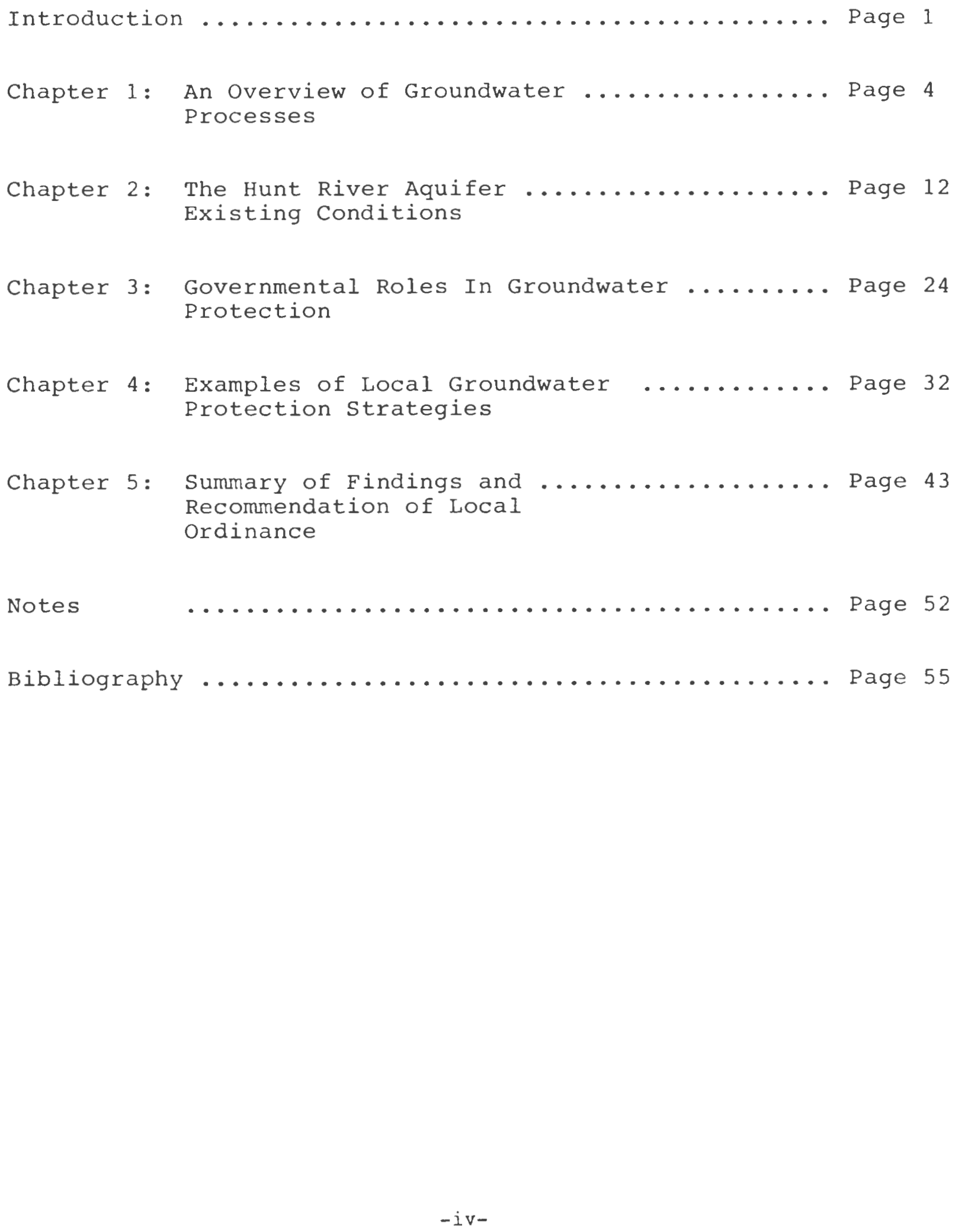




\section{LIST OF FIGURES \& GRAPHS}

Figure 1: Hydrologic cycle ................... Page 10

Figure 2: Hunt River watershed and sub-watersheds ...................................... 13

Figure 3: Hunt River primary recharge area .......... Page 15

Figure $4:$ Soil septic suitability ............... Page 17

Figure 5: Land use/zoning designations ............ Page 19

Graph 1: Percentage of land use zoning classifications within the Hunt

River primary recharge area ............ Page 20

Figure 6: Vegetation survey, Hunt River

primary recharge area ......................... 23 


\section{INTRODUCTION}

A groundwater reservoir is an important and sensitive natural resource. Many communities depend on groundwater for part or all of their potable water supply; other aquifers have a significant potential to serve as public water supplies as population growth occurs in the coming years.

The Hunt River, known in its lower reaches as the Potowomut River, forms a natural boundary between the towns of East Greenwich and North Kingstown for approximately 3.5 miles. The river is directly associated with a more extensive groundwater reservoir which is recognized in the Rhode Island "208" Areawide - Water Quality Management Plan as an important source for present and future drinking water supplies. $^{1}$

The town of North Kingstown has addressed the need to protect the ecologically significant groundwater reservoir associated with the Hunt River by implementing groundwater overlay districts, incorporated in the town's zoning ordinance. 2 Within the overlay districts, permitted uses and density of uses are regulated in an effort to preserve the quality of the town's principal source of drinking water.

The town of East Greenwich does not presently have a specific provision in its zoning ordinance to address the need to protect the Hunt River aquifer's water quality and quantity for potential future use.

The development of a groundwater protection ordinance that can be cooperatively implemented by the towns of East 
Greenwich and North Kingstown to protect the Hunt River aquifer's water quality and quantity is the goal of this report.

Chapter one is an overview of the general characteristics of groundwater, in which the natural processes of groundwater sustenence is discussed. Familiarity with these characteristics if the first step in developing important groundwater resource protective measures at the municipal level.

Chapter two defines and illustrates the Hunt River watershed and its boundaries. In evaluating the present natural conditions and urbanization of the Hunt River watershed, a "picture" develops as to what potential problems can or should be addressed.

A summary of existing ordinances and legislation pertaining to groundwater protection is presented in Chapter three of this report. Reviewed are relevant federal, state, and town ordinances presently in effect that regulate (directly or indirectly) land uses in the Hunt River groundwater area. The purpose of Chapter three is to determine what regulations presently exist that help protect the groundwater resource, consequently revealing protection deficiencies.

The fourth chapter focuses on various groundwater protection strategies that have been developed at the municipal level, in an effort to reveal what approaches are best suited for the Hunt River groundwater area as it 
presently exists.

Reflecting on the information collected in the making of this report, a summary of findings and recommendations is presented in chapter five. Included is an ordinance suggested to be cooperatively implemented by the towns of East Greenwich and North Kingstown in protecting the significant groundwater resource. 


\section{CHAPTER ONE:}

\section{AN OVERVIEW OF GROUNDWATER PROCESSES}

In creating strategies to protect potable groundwater supplies associated with the Hunt River, it is first helpful to develop an understanding of what groundwater is and what are the general characteristics of a groundwater aquifer.

\section{TERMINOLOGY}

Following is a summary of terminology often used to described the functions and characteristics of groundwater.

Groundwater: Water beneath the surface of the ground in a "saturated zone," where every pore space between soil particles is saturated with water.

Unsaturated Zone: Also referred to as the "zone of aeration," the unsaturated zone is the area closest to the surface (above the saturated zone) characterized by open space between soil particles only partially filled with water. ${ }^{3}$

Water Table: The top of the saturated zone, being the minimum depth at which groundwater supplies can be found at a given location. 
Hydrodynamic Dispersion: The process by which particulates and liquids travel from the external land surface through the soil levels and downward due to gravitational forces; water "percolates" through the unsaturated zone until it reaches the saturated zone.

Porosity: A characteristic of soil material relating to the capacity of the material to hold water. Porosity is expressed as a percentage of the total volume of the material. 4

Permeability: A characteristic of soil material relating to its ability to yield water; if pore spaces are large, water will move through the material more readily.

Aquifer: A geological formation that is capable of yielding a significant amount of water to a well or spring, often characterized as loose (unconsolidated) surficial deposits underlined by a relatively impervious layer such as clay or bedrock.

Aquifers can be described as being confined or unconfined. An unconfined aquifer has a water table as its upper boundary; above the water table is the unsaturated zone, where interconnected pore spaces are open to the atmosphere. 5 A confined aquifer, also called an "artesian" aquifer, is found between layers of clay or other materials of low permeability; groundwater is under pressure because 
the aquifer is confined between the impermeable layers and is usually recharged at a higher elevation than the top confining layer. 6

Saturated Thickness: A term relating to the thickness of an aquifer at any given location and time measured from the bottom of the saturated zone up to the water table.

Transmissibility: A term used in measuring an aquifer's ability to yield groundwater, a rate usually measured in gallons per day (gpd) per foot. 7

Watershed: Also referred to as a drainage basin, a watershed is a land area that drains surface runoff to a stream, river, pond, lake, or other wetland. The source of groundwater in each watershed is generally the precipitation that falls within the land area. The outer perimeter of a particular watershed is a function of surface topography (elevation contours).

Primary Recharge Area: The surface area directly overlaying an aquifer, where rain and melting snow percolate into the ground to recharge the groundwater supply. The primary recharge area may also include adjacent areas of stratified drift whose saturated thickness is insufficient to be part of the aquifer. From this zone water migrates into the stratified drift deposit. ${ }^{8}$ 
Secondary Recharge Area: Groundwater recharge which occurs indirectly or is induced. For example, if a well is located near a surface water body to which groundwater normally discharges, the water table gradient can be reversed and water will flow toward the well. This type of induced recharge may be the primary source of water for wells in stratified drift near large surface water bodies. ${ }^{9}$

Surficial Deposits: Sand, gravel, soils, rock, and other unconsolidated (loose) material that lie on top of bedrock.

Bedrock: Rock that lies beneath surficial deposits, also called "ledge". Bedrock can serve as an aquifer only if enough interconnected fractures within the bedrock exists to hold and transmit water.

Stratified Drift: Sediment deposited by meltwater from glaciers which covered the area between 10,000 and 13,000 years ago. Interbedded layers of sand, gravel, silt, and clay comprise the sediment. Rhode Island's major aquifers are stratified drift aquifers, yielding water from pore spaces between individual particles.

Glacial Till: Glacial debris consisting of an unsorted mixture of all sizes of soil and rock fragments, usually not very porous or permeable (a poor aquifer material). 
Drawdown: A lowering of the water table in the area around a well where the pumping of groundwater occurs; instead of moving toward its natural discharge area, groundwater within the influence of the pump flows towards the well in every direction.

Cone of Depression: A term used to describe the area around a pumping well where a "drawdown" of the water table occurs.

Contamination plume: A term used to describe the concentrated form of pollution as it moves through groundwater. Unlike pollutants in surface water, which are diluted as they mix with water, pollutants in groundwater occur in concentrated slugs, because little dispersion or mixing occurs.

\section{THE GROUNDWATER SYSTEM}

Precipitation that falls to the earth's surface will continue as part of the hydrologic cycle in a number of ways. Some water will evaporate directly back into the atmosphere. Other water is utilized by plants and returns to the atmosphere as a result of evapotranspiration. Also, water will flow over land surfaces as "surface runoff," flowing into surface waterbodies. That portion of the water that falls on land and is absorbed directly into the soil is the sustenence of groundwater systems. 
Annually is this country, rainfall puts back about ten times as much water as is pumped out of the ground each year. 10 While the ratio of rainfall to usage is high nationally, in many communities it is less due to low annual rainfall and/or excessive demand. After runoff and evaporation, about 30 percent of precipitation seeps through the upper layers of soil called the unsaturated zone. The amount of water infiltrated varies with the temperature and intensity of precipitation, elevation and slope of land surfaces and permeability as determined by soil characteristics and as modified by plants or animals. 11

Moisture not absorbed by plants seeps down below the water table to the saturated zone where all pore spaces are filled with water. As this recharge water enters the saturated zone, it may move horizontally towards areas of lower pressure or into deeper aquifers where it is either stored permanently or can again move laterally. Much of this recharge will eventually find its way into streams, lakes, and wetlands. 


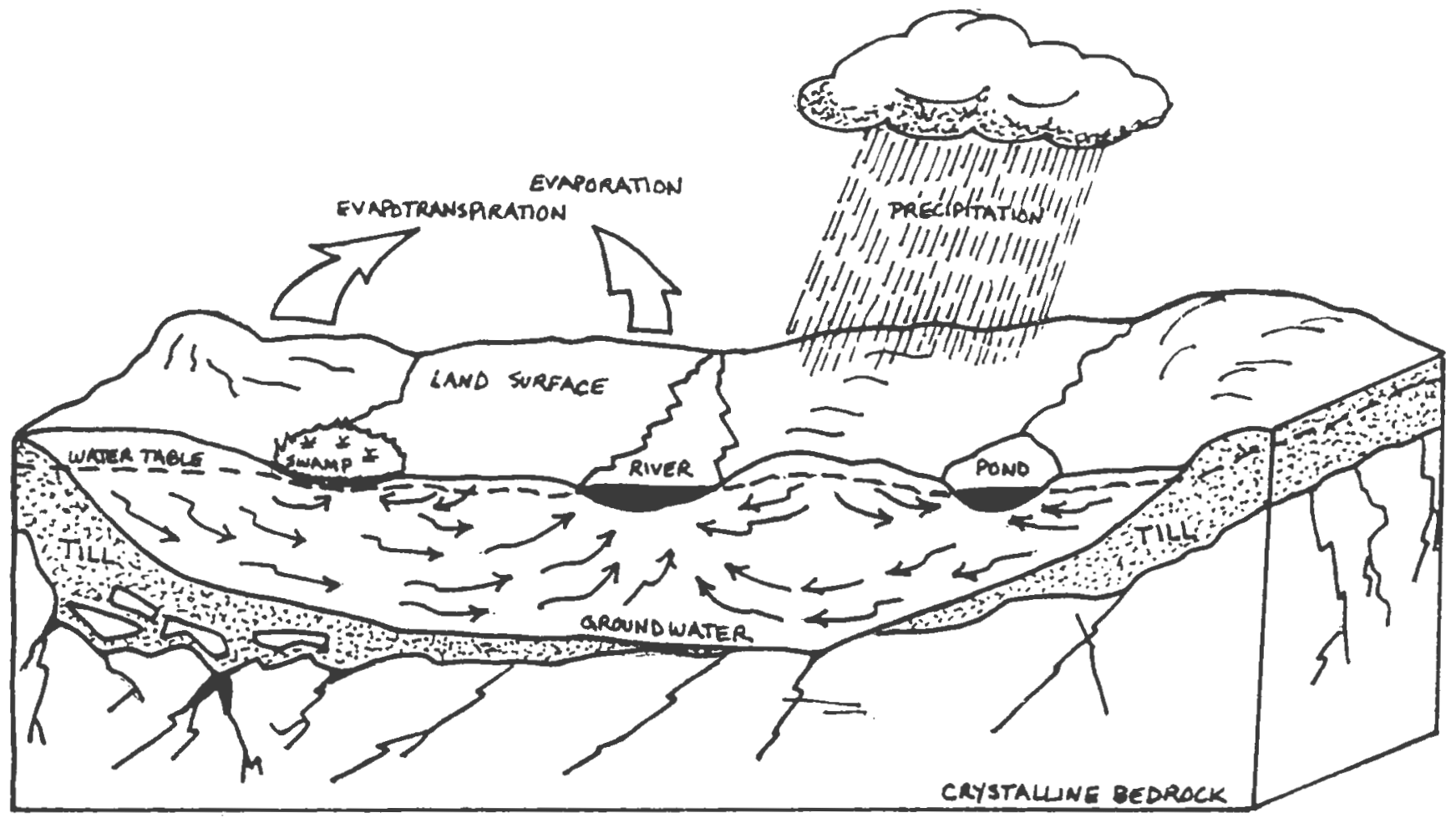

Figure 1. Hydrologic cycle.

Source: Rhode Island Statewide Planning Prograni Technical Paper No. 98, Sept. 1981

Surface and ground water differ in a number of significant ways. Surface water is visible, generally swift moving, and self-cleaning. In contrast, ground water is consealed out of sight, moves as slowly as 20 feet a year, and contaminants tend to move as "plumes or slugs" rather than to diffuse through the aquifer, making the contaminated areas more concentrated and longer lasting. Consequently, monitoring aquifers is difficult and expensive and not 
always possible. Almost all groundwater pollution has been discovered only after a drinking water source has become affected. Thus, groundwater protection management should be geared towards prevention rather than response to contamination. 


\section{CHAPTER TWO}

THE HUNT RIVER AQUIFER

EXISTING CONDITIONS

The quality and quantity of groundwater in the Hunt River Aquifer is directly effected by land use within the Hunt River watershed. In this chapter, watershed characteristics are presented and analyzed. Information pertaining to the study of natural features and urban influences is divided into the following categories: the Hunt River Aquifer primary and secondary recharge areas; soils septic tank suitability; land use designations as characterized by zoning districts; and vegetation communities.

THE HUNT RIVER WATERSHED AND AQUIFER RECHARGE AREAS

The Hunt River is fed by a number of "feeder" brooks: Frenchtown Brook; Fry Brook, Scrabbletown Brook; Mawney Brook; and Sandhill Brook. In delineating the watershed boundaries of the Hunt River, it is necessary to include these feeder brooks within the confines of the overall watershed. As part of the Hunt River watershed, each of the brooks in turn has its own lesser watershed. Figure 2 illustrates the Hunt River watershed and subsequent smaller "sub-watersheds" within the defined area. Watershed boundaries were determined by examining land elevation contours, which have a direct effect on surface runoff directional flow. 


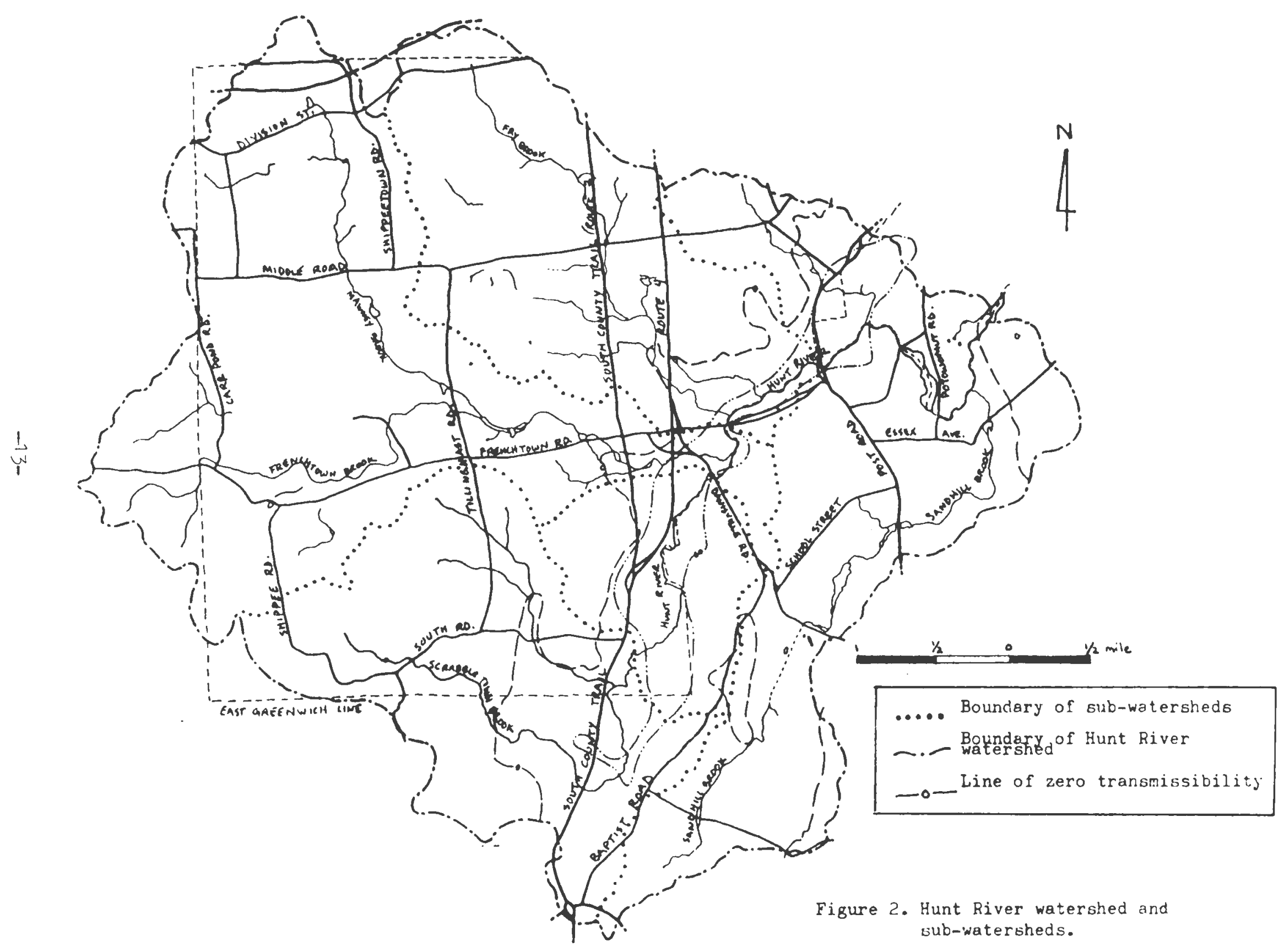


The overall watershed of the Hunt River encompasses the majority of East Greenwich and the northwestern portion of North Kingstown; an area approximately 21 square miles in size.

In establishing a study area for the purpose of this report, a primary recharge area within the overall watershed of the Hunt River was determined by using a boundary of "zero transmissibility," as set forth in the UsGs publication Hydrologic Characteristics and Sustained Yield of Principal Groundwater Units, Potowomut-Wickford Area, Rhode Island (see figure 3 ). 12

Transmissibility, as earlier defined in chapter one, refers to the rate at which water can be withdrawn from groundwater reserves, measured in gallons per day per foot (gpd). The delineated primary recharge area reflects the location of direct recharge into the Hunt River groundwater aquifer, from water infiltrating through soil directly above the aquifer.

Although it is important to consider the impact of urbanization within the overall watershed of the Hunt River as it affects groundwater quality, the scope of this report focuses on the primary recharge area as the principal location for needed protection strategies. 


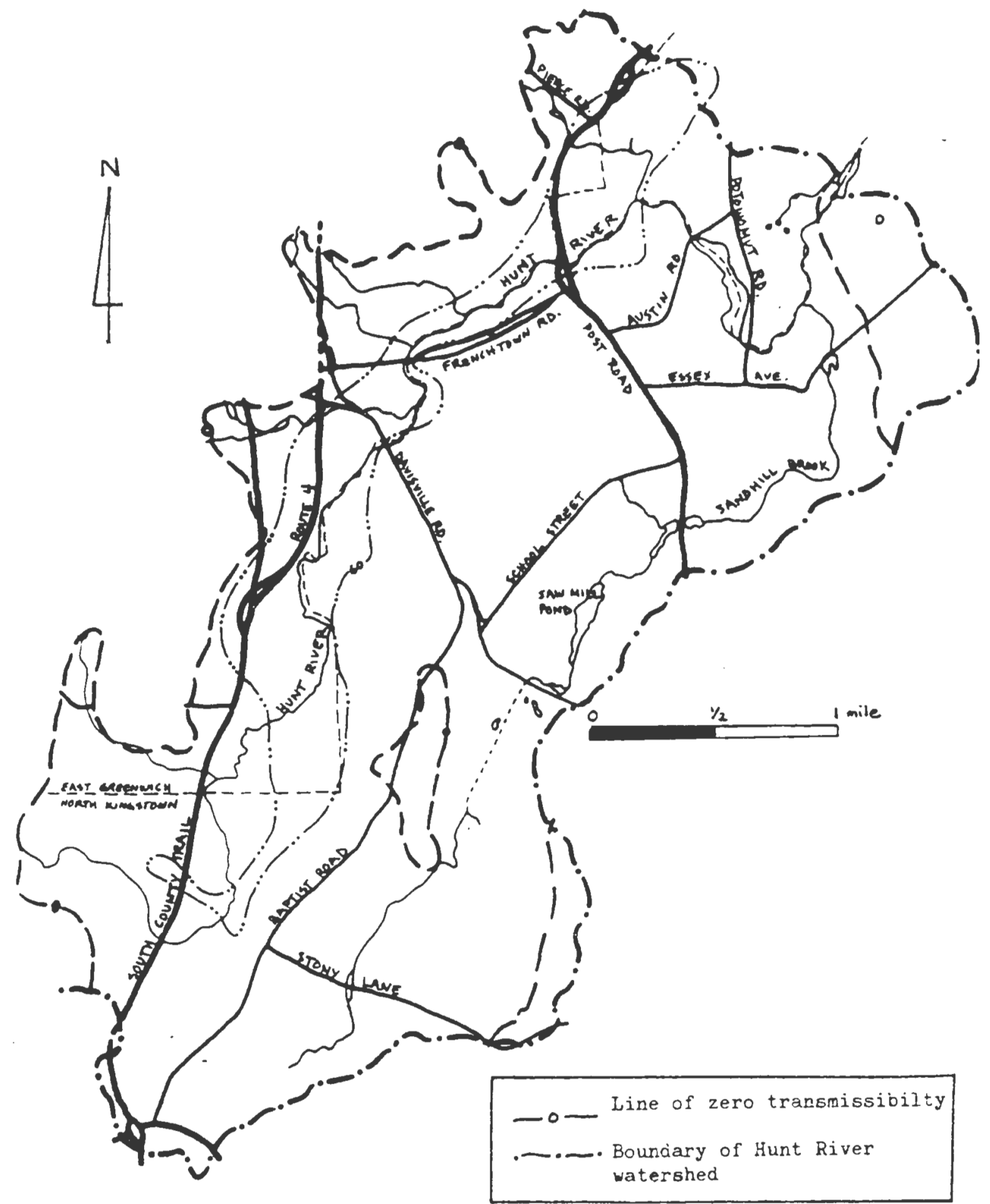

Figure 3. Funt River primary recharge area.

Source: U.S.D.I. Geological Survey hater-Suppiy Paper 17?5, Plate 2 
SOIL CHARACTERISTICS

In researching the characteristics of soils found in the primary recharge area of the Hunt River, seventy six (76) soil classifications exist as defined in the soil Conservation Service (SCS) Soil Survey of Rhode Island $(1981)$.

The septic suitability of soil is determined in the SCS survey through assessment of the properties and features of soil that affect absorption of effluent such as permeability, depth to seasonal highwater table, depth of bedrock, and susceptibility to flooding. ${ }^{13}$ Figure 4 illustrates the various soils as they are categorized relative to septic tank absorption field suitability.

Within the primary recharge area, approximately $30 \%$ of the soils are classified as "severe" in constraint concerning septic tank absorption field suitability; approximately $10 \%$ of the area can be classified as being "moderate," and about $40 \%$ as being "light" in constraint. The remaining land area is classified as urban land or gravel pits as delineated in the scs survey; approximately $20 \%$. This information is presented to give an indication as to where within the primary recharge area soil characteristics play a role in determining preferred locations for future development requiring septic tank absorption fields. 


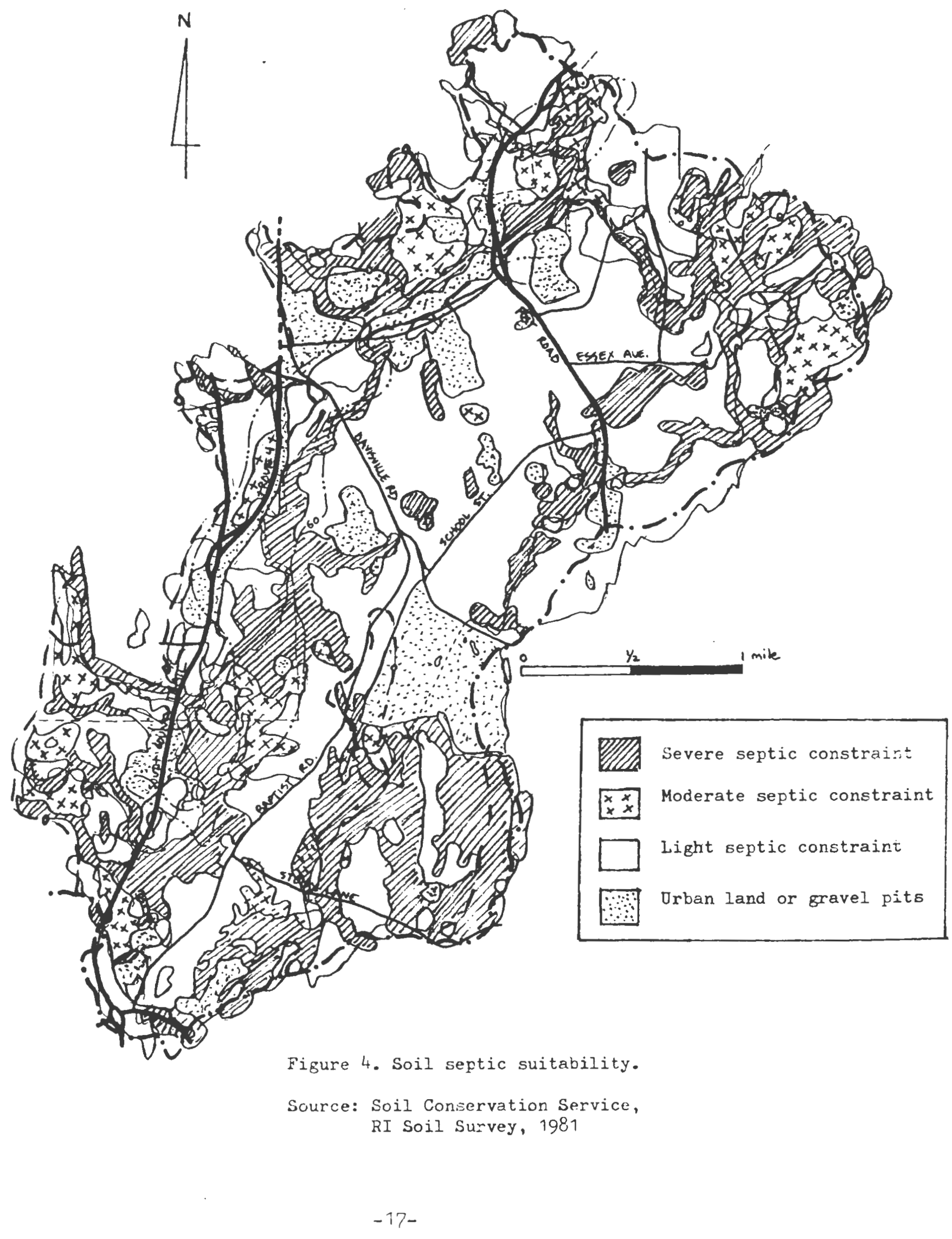




\section{EXISTING LAND USE AND DESIGNATIONS}

In evaluating the present land use conditions within the primary recharge area of the Hunt River, zoning district information was obtained for the towns of East Greenwich and North Kingstown, and is illustrated in Figure 5. Using the zoning designations as a reference, land adjacent to the Hunt River is primarily medium and low density residential (requiring at least .5 acres per dwelling). Within the overall primary recharge area, however, there are locations of industrial and commercial districts. 


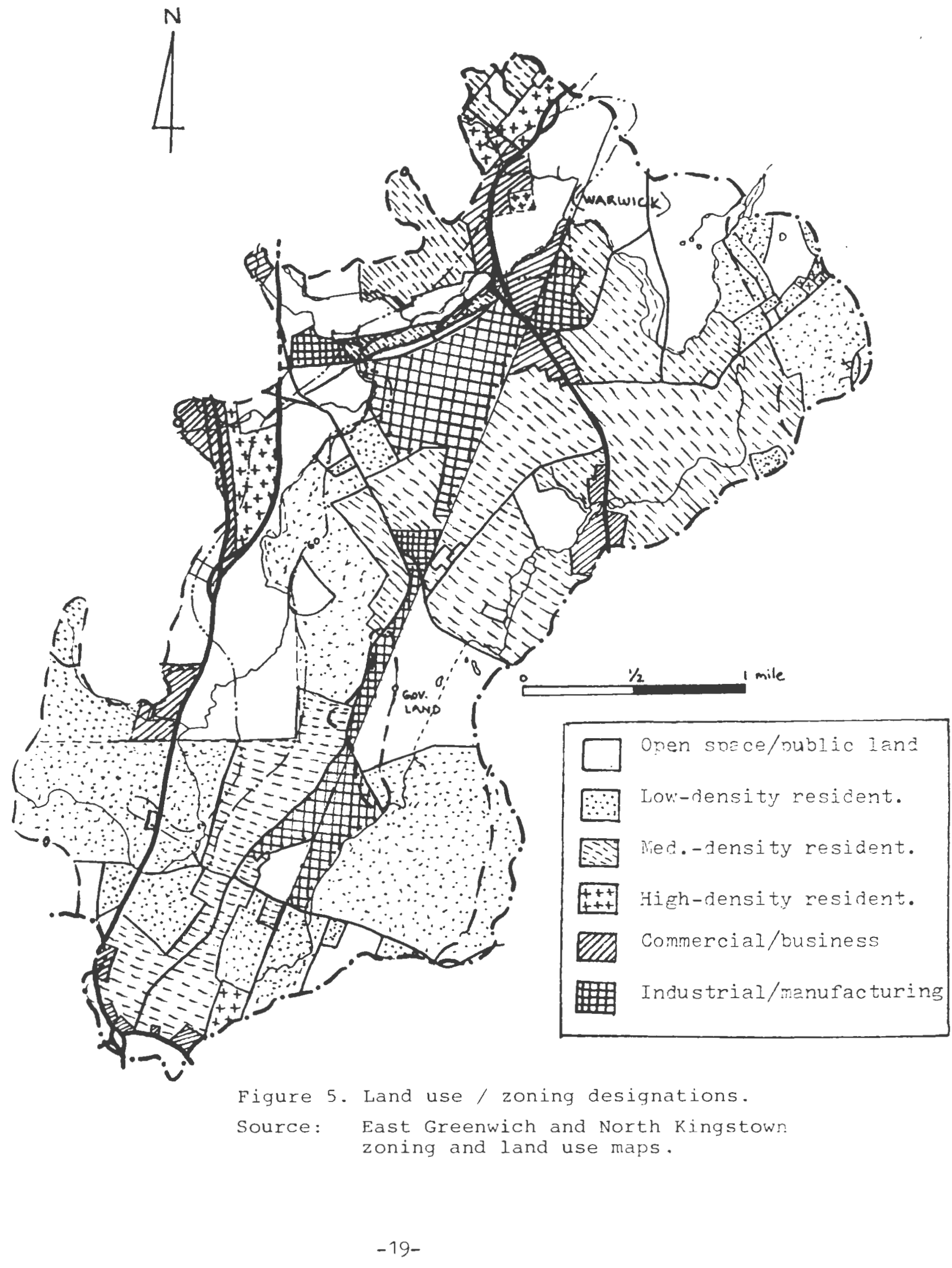


In estimating the percentages of the various uses with the primary recharge area, a grid system was used overlaying the zoning districts as depicted in Figure 5. Graph 1 is a breakdown of the estimated percentages of the various land uses as reflected in the zoning classifications.

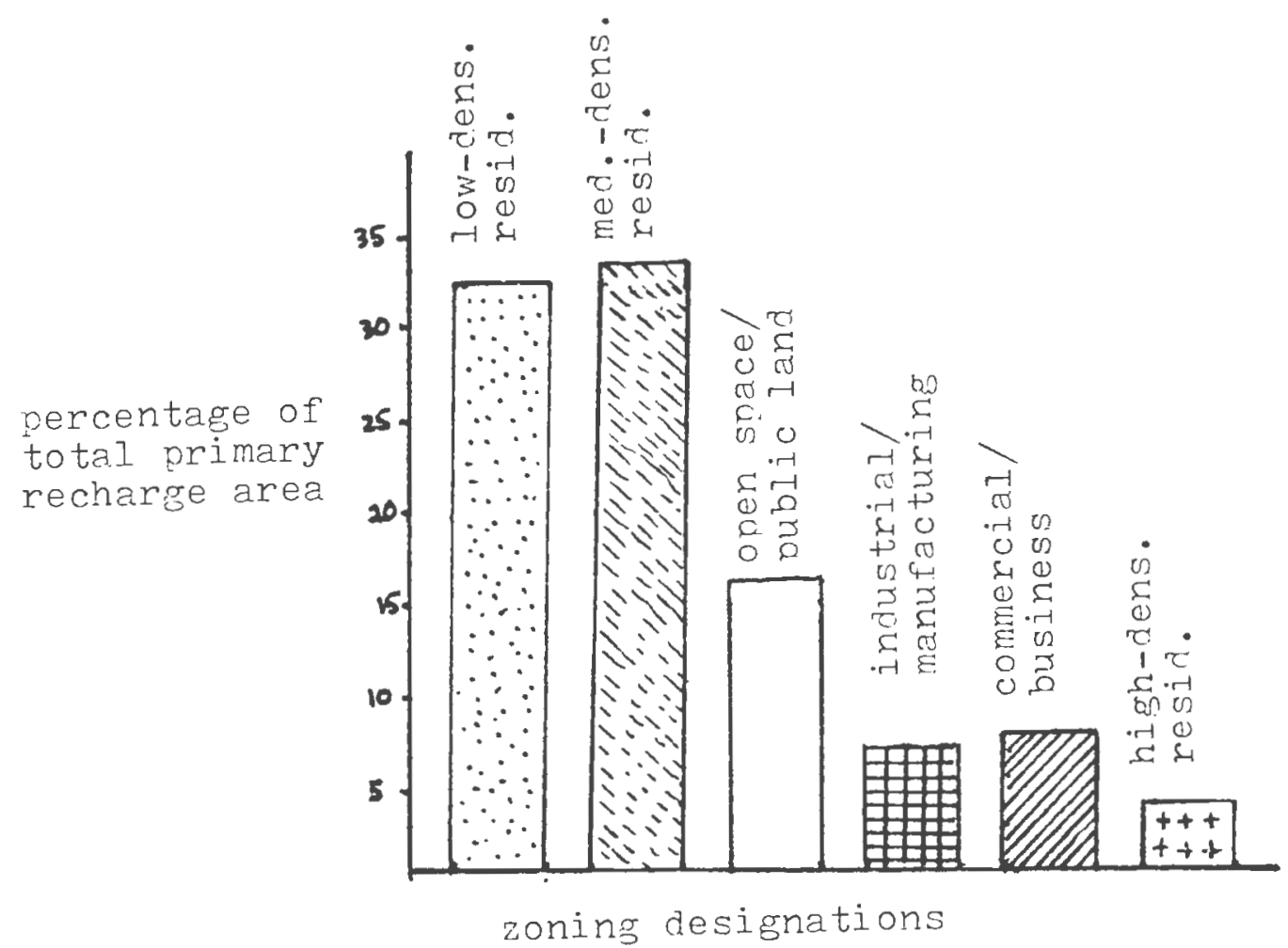
Graph 1. Percentages of land use/zoning classifications
within the Hunt River primary recharge area. 
The information in Graph 1 indicates that approximately 658 of the primary recharge area is classified as medium or low density residential. Approximately $4 \%$ of the areas is high density residential (1,400-15,000 square feet per lot), while commercial business and industrial zoned areas represent approximately 158 of the recharge area. The open space/public land category, which also includes recreational and government land, equals about $16 \%$ of the total area.

With almost two-thirds of the area being designated for medium or low density residential, an important issue of concern regarding groundwater quality protection is the regulation of individual subsurface disposal systems (ISDS) for residential purposes. Although this report does not focus on ISDS permitting standards, this author acknowledges that a cooperative approach by state and local entities to regulate and monitor the systems is an important aspect of groundwater protection.

While commercial and industrial areas only represent approximately $17 \%$ of the primary recharge area, some of those areas are in close proximity to the Hunt River (ie Brown and Sharpe). Also, it is important to consider the impacts of possible future commercial/industrial development that may occur in the vicinity of the Hunt River in relation to arterial roadway improvements an development.

When evaluating urban uses as they exist and as they 


\begin{abstract}
are designated for the future, it is important to realize the natural features of the proposed use areas; features such as the distinguishable vegetation/habitat communities located in the area. For this report, vegetation types were obtained from the maps "The Forest and Wetland Vegetation Types of Rhode Island," prepared by the Agricultural Experiment Station, University of Rhode Island, Department of Forestry. Figure 6 presents the vegetation classifications within the primary recharge area.
\end{abstract}




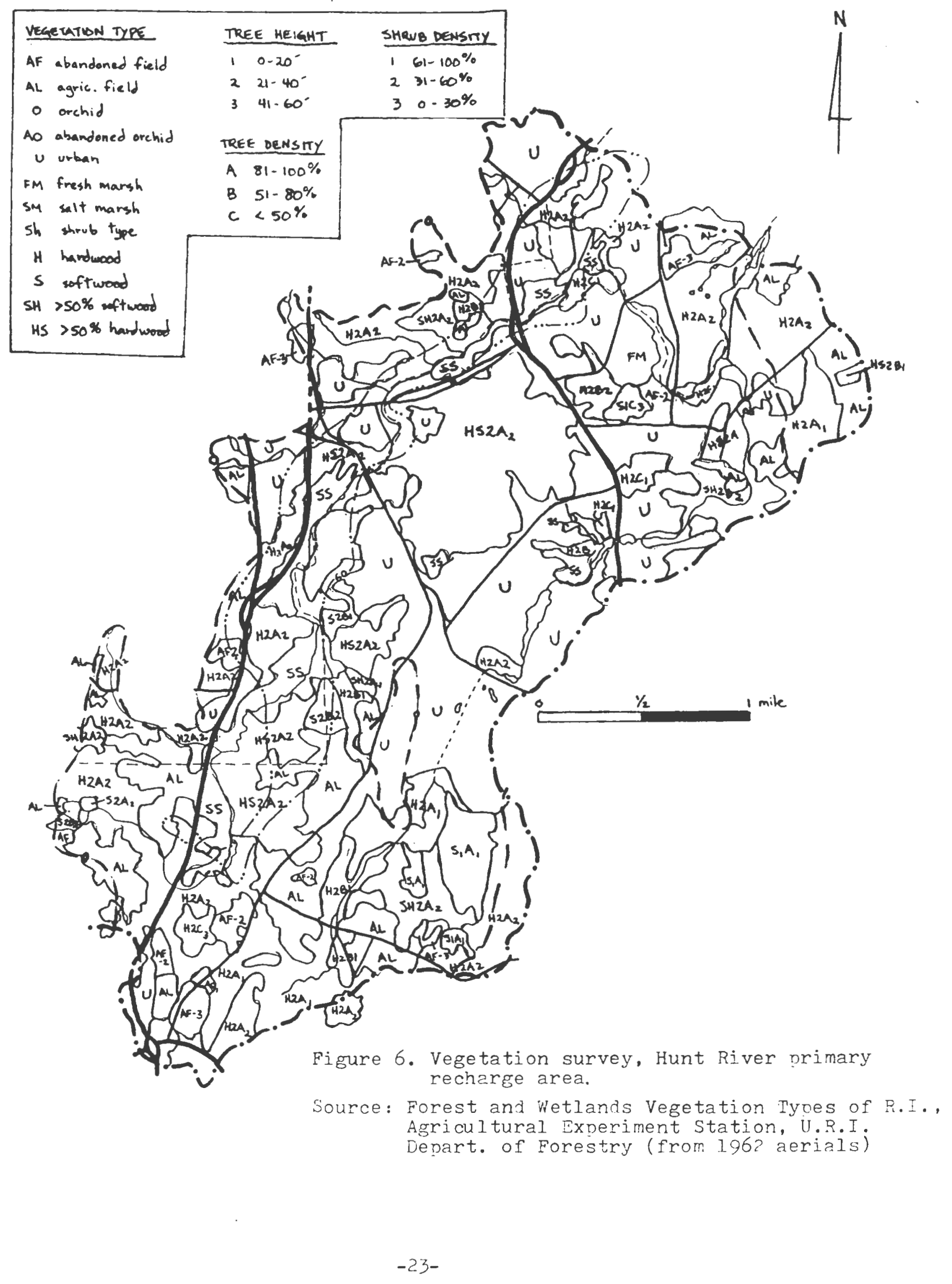




\section{CHAPTER THREE :}

\section{GOVERNMENTAL ROLES IN GROUNDWATER PROTECTION}

The protection of groundwater supplies is addressed in varying degrees by government on the federal, state, and local levels. In the case of the Hunt River groundwater system, a number of governmental programs affect the resource's protection, both directly and indirectly. The creation of a local groundwater protection ordinance would be beneficial in having an immediate impact on the regulation of potentially contaminating uses within the recharge area.

Presented in this chapter is a brief overview of legislation existing on the various governmental levels that are related to the protection of groundwater resources.

\section{Federal Programs}

The federal government does not directly intervene over the protection of local groundwater systems, in that land use is controlled more directly at the state and local levels. Federal statutes like the clean water Act, The Safe Drinking water Act, the Resource Conservation and Recovery Act, and the Toxic substances control Act are intended, in part, to prevent groundwater contamination from various sources, but these statutes prescribe no explicit controls to manage groundwater. ${ }^{14}$ with the exception of groundwater located on federal lands, Congress intended that states have direct authority over their groundwater resources.

$$
-24-
$$


Section 208 of the Federal Clean water Act specifically recognizes the relationship between land use and water quality, requiring state programs that "regulate the location, modification, and construction of any facilities... which may result in any discharge." This section also focuses on the institution of land use controls to minimize pollution from nonpoint sources such as agriculture and construction. 15

The Resource Conservation and Recovery Act (RCRA) is important in that it addresses a severely dangerous form of groundwater contamination: improper management of hazardous wastes. States may administer RCRA in conjunction with their own hazardous waste management programs so long as their statutory and regulatory authority is "substantially equivalent" to RCRA. The state of Rhode Island has revised its regulations in order to obtain requisite federal authorization. 16

The Federal Safe Drinking Water Act of 1974 provides that federal funds be limited in areas where aquifers are in danger of contamination. The Act is intended to combat groundwater contamination by way of the land disposal of wastes. $^{17}$ Part of the Safe Drinking water Act is the Underground Injection Control (UIC) Program, which addresses the disposal of waste in wells. The UIC program authorizes and funds state efforts to develop inventories of disposal wells and assess the impact of well disposal on underground drinking water sources. 18 In that there are relatively few 
waste disposal wells in Rhode Island, however, the UIC program is not of great significance in that respect. In the future, though, the program may be useful in controlling future municipal and industrial waste disposal practices.

The planning provisions of the UIC program include an inventory of current and potential underground drinking water sources. Such an inventory would help facilitate the recognition of significant groundwater resources in the state; recognition that could lead to special regulation considerations.

There are a number of reasons why groundwater management is more suitable for state and local jurisdictions, rather than at the federal level. Firstly, geohydrological conditions vary a great deal from region to region; it would be difficult for a federal agency to develop uniform standards and regulations that would be appropriate for the variety of resources.

In addition to the varying physical characteristics of groundwater nationally, states associate groundwater rights with property rights, subjecting the resource to each state's police powers, common law, and state legislative authority. It is fitting that the governmental level with the most direct interaction with a particular resource have the more substantive regulations and maragement policies related to that resource. 
State Authority

With reference to the federal statues previously mentioned, the federal government has passed on the majority of control over groundwater to the state level. In the past, Rhode Island has relied heavily on the common law to settle groundwater allocation disputes and as a basis for state legislation. 19 The historical basis of groundwater allocation in the state is the "doctrine of absolute ownership." Under the doctrine, the user may appropriate as much groundwater as he can withdraw from any point on his property and, provided he has not diverted water maliciously, he may not be held liable to an abutting landowner, or anyone, for damages resulting from his unrestricted use. 20 In cases of contamination, the basis for the defendant's liability is negligence.

In using Rhode Island common law as a means to protect groundwater resources, a number of drawbacks exist. First, there has been a lack of scientific knowledge of groundwater, and the courts deemed impossible the application of systematic rules. Also, complaints of groundwater contamination that arose dealt only with individual water supplies and not public sources. 21 Even with scientific evidence, the common law only addresses problems as they arise and does not prevent contamination and depletion of groundwater. Rhode Island has legislation that is not directed specifically toward groundwater management, yet contributes by addressing hazardous wastes, solid waste, and individual 
subsurface disposal systems. The Rhode Island Hazardous Waste Management Act (1981) was formulated to control certain activities that have a serious potential to contaminate groundwater supplies. The Act authorizes the Department of Environmental Management (DEM) to regulate storage, transport, treatment, and disposal of any waste that the Act defines as "hazardous." 22

The Department of Environmental Management also has authority over solid waste management and disposal of septage in subsurface systems. DEM solid waste regulations are geared to require adequate distances between individual systems and private wells through the provision of a buffer zone between the systems and the water table. The septage is thereby filtered through soil, and, in theory, rendered harmless before reaching the groundwater. 23

Rhode Island has significant new legislation to address groundwater protection in the form of the Groundwater Protection Act, which requires the director of DEM to classify a.l groundwater sources in the state and develop water quality standards for each classification, specifying maximum contaminant levels. The department is authorized to conduct a study of the quantity and quality of water available to specific areas for drinking water; the present and projected demands form water; and recommendations for use of groundwater resources, works or special districts that may be necessary, land use measures where appropriate, and local 
and regional planning and programs for water use and management. 24 The department is also to identify actual and potential harm to significant aquifers and to develop a plan for protecting them.

The state of Rhode Island already recognizes the Hunt River and its associated groundwater aquifer as a significant groundwater reservoir, as indicated in the "208" Areawide Water Quality Management Plan (November, 1982). The development of local regulations is an important step contributing towards the protection of groundwater associated with the Hunt River; a step that would compliment actions the state may take to implement the Groundwater Management Act.

\section{Local Regulation}

Although groundwater recharge areas often extend into several municipality jurisdictions, as is the case with the Hunt River primary recharge area, local governments should considered utilizing their authority to impose land use regulations for that area within their own jurisdictional boundaries. Optimumly, localities will coordinate their protection efforts to achieve consistency of management throughout the recharge area.

Two Rhode Island statutes provide groundwater protection authority to local governments; the Rhode Island Zoning Enabling Act, and the Hogan Act, which is as amendment to the Hazardous Waste Management Act.

The Rhode Island Zoning Enabling Act empowers local 
government to restrict land use so as to protect public health and safety, avoid overcrowding, and provide adequately for such amenities as water supply and sewerage. 25 It is important that regulations relying on the enabling act as a basis be closely tied to sound factual evidence, however, in that property owners are protected under the Fifth Amendment to the U.S. Constitution whereby private property cannot be "taken for public use, without just compensation."26 Restrictions designed to protect environmentally sensitive areas will necessarily limit the use of private lands; factual evidence as to the significance of a groundwater source is therefore important is substantiating protective measures.

The Hogan Act, as an amendment to the Hazardous Waste Management Act, states:

"No hazardous waste, including septic waste, shall be disposed of in an area overlaying an actual, planned, or potential underground drinking water source shown on the maps of the USGS and the Rhode Island water Resources Board, providing such underground drinking water source has been designated, on the basis of hydrogeological data, as a future or potential municipal water source by the city or town in which the underground water source is located and furthermore providing there is a local ordinance relating to groundwater aquifer zones." 27

The state's Groundwater Protection Act and the Hogan 
Act specifically encourage local governments to adopt ordinances to protect recognized significant groundwater reservoirs through the regulation of land use, as enabled through state legislation. The town of North Kingstown has already addressed groundwater concerns with a groundwater Overlay District within their zoning ordinance; a groundwater protection ordinance applied cooperatively by the towns of East Greenwich and North Kingstown would be an even more affective approach to protecting the Hunt River Groundwater Aquifer. 


\section{CHAPTER FOUR}

\section{EXAMPLES OF LOCAL GROUNDWATER PROTECTION STRATEGIES}

In establishing a groundwater protection ordinance on the local level, it is important to consider aspects of existing land use, trends, and specific characteristics of the aquifer to be protected. It is helpful however, to study local ordinances established by other municipalities for examples of ordinance format and regulation. In this chapter, a number of "model" ordinances are reviewed to determine if they have traits that would be appropriate for the protection of the Hunt River groundwater supplies.

(1) Aquifer Protection Ordinance: Androscoggin Valley

Regional Planning Commission

As a part of the Section 208 Areawide Waste Treatment Management Program, the Water Quality Planning staff of the Androscoggin Valley Regional Planning Commission (in Maine) developed a Technical Memorandum (September 1977) which includes a model aquifer protection ordinance. 28

The model aquifer protection ordinance is presented as an "overlay" zone that is superimposed over an underlying existing zone, and the additional provisions of the overlay zone take precedent over the requirements of the underlying existing zone(s).

The purpose of the ordinance is described as ... "for the promotion of the health, safety and general welfare of its 
residents, and to protect the groundwater resources of the town from adverse development or land-use practices (such as but not limited to the disposal or storage of solid wastes, sludge, subsurface waste disposal, road salt materials, gas or other petroleum productsl that might reduce the quality and quantity of water that is now .... and in the future will be ... available for use by municipalities, individuals and industries." 29 The model ordinance further suggests the establishment and delineation of water protection areas by use of a map at a scale of 1 inch to 1,000 feet. The map would indicate the location of the aquifer and associated surface recharge areas. A provision of the ordinance also allows for case-by-case delineation of protection area boundaries where there is doubt or dispute over exact bounds. The burden of proof for determining the disputed boundary shall be upon the owner(s) of the land in question. 30 The Androscoggin Valley model ordinance sets forth use regulations, prohibiting certain uses within the water protection areas, while requiring a conditional-use permit for other specified land uses. Following is a listing of the prohibited uses and those uses requiring a conditional use permit:

\section{$\underline{\text { PROH IBITED USES }}$}

- Disposal of solid wastes, other than brush and stumps.

- Storage and/or transmission of petroleum products.

- Disposal of liquid or leachable wastes (excluding 


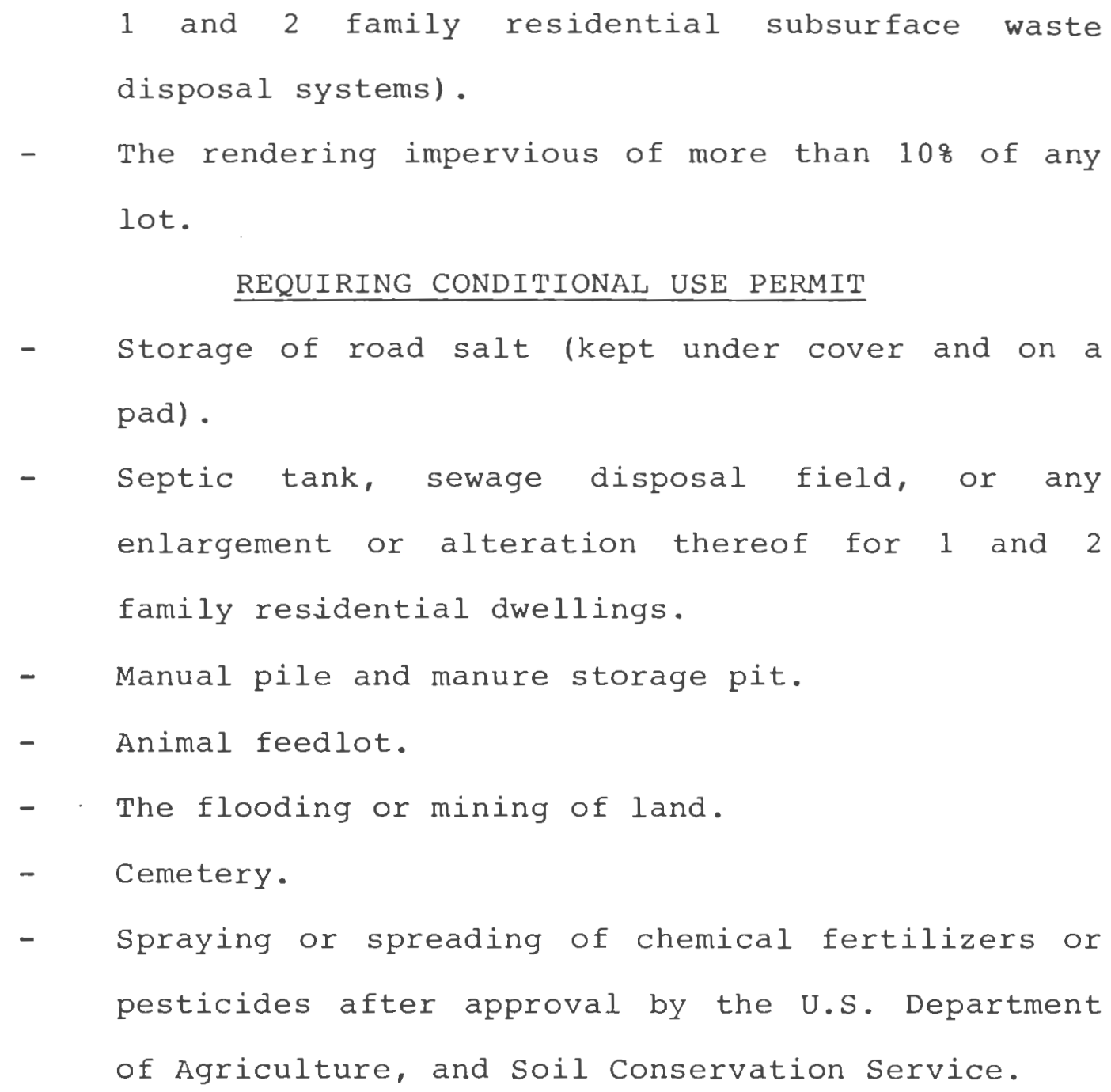

The conditional-use permit is issued only after a site plan of a proposed project is submitted and approved by the Planning Board (with conditions) after a public hearing.

(2) The Handbook for Rhode Island Conservation Commissioners: Model Aquifer Ordinance

In 1982, a private non-profit agency known as Rhode Island Projects for the Environment, Inc. (RIPE) published The Handbook for Rhode Island Conservation Commissions, in 
cooperation with the Rhode Island Association of Conservation Commissioners (RIACC). 31 within The Handbook, a model aquifer ordinance is presented.

The purpose of the aquifer protection ordinance is described as "to protect public health by preventing contamination of the ground and surface water resources providing water supply to the town." The model ordinance also makes reference to findings set forth in the water Quality Management Plan of Rhode Island prepared pursuant to section 208 of the Federal Clear water Act. 32

The model aquifer protection ordinance presented in The Handbook is similar to the Androscoggin Valley ordinance in that it proposes an overlay zoning district defined by a map reference and/or boundary narrative. The ordinance does, however, present a more extensive listing of prohibited uses within the aquifer protection zone. As the Androscoggin Valley ordinance required a conditional-use permit, The Handbook's model ordinance also allows certain uses only after planning board review.

\section{PROHIBITED USES}

- Sanitary landfills, junkyards.

- Municipal sewage treatment facilities with on-site disposal of primary or secondary treated effluent.

- Car washes.

- Road salt stockpiles.

- Any other uses which involves as a principal activity the manufacturer, use, storage, transpor- 
tation, or disposal of toxic or hazardous materials, except as allowed by a "special permit."

- Dry cleaning establishments.

- Boat and motor vehicle service and repair.

- Metal plating.

- Chemical and bacteriological laboratories.

\section{SPECIAL PERMIT USES}

- Transportation terminals.

- Any principal use involving the sale, storage, transportation of fuel oil or gasoline.

- Any use involving the retention of less than 10-30\% of the lot area in its natural state with no more than minor removal of existing trees and ground vegetation, or rendering impervious more than $10 \%$ of the lot area.

- Any use involving on-site disposal of process wastes from operations other than personal hygiene and food for residents, patron and employees.

- Any use (other than a single-family dwellingl with a sewage flow exceeding 10 gallons per $1,000 \mathrm{sq}$. ft. of lot area or exceeding 15,000 gallons per day regardless of lot area.

- Any use involving the generation of toxic or hazardous materials in quantities greater than associated with normal household use. 
(3) Conservation Law Foundation of New England, Inc.: Model Groundwater Protection District

The model ordinance set forth in the publication Underground Petroleum Storage Tanks: Local Regulation of a Groundwater Hazard put out by the Conservation Law Foundation of New England (1984) follows the same pattern as those model ordinance previously reviewed; a listing of prohibited uses and special permit uses are specified. In addition, this model ordinance also specifies permitted uses. 33

As does the Androscoggin Valley model ordinance, this ordinance puts the burden of proof on the land owner when disputes arise as to the boundary delineations of the overlay district.

Listed below are samples of uses permitted, those prohibited, and uses requiring a special permit. Rather than repeat the listing of uses already described in the pervious model ordinances, this listing covers specified uses not previously addressed.

\section{PERMITTED USES}

(provided all necessary local/state/federal approval obtained)

- Conservation of soil, water, plants and wildlife.

- Outdoor recreation, not involving the use of motor vehicles or motor boats.

- Foot, bicycle, and horse paths and bridges.

- Maintenance and repair of any existing structure, provided there is no increase in pervious surface. 
- Normal operation of water control, supply and conservation devices.

- Residential development, provided no more than 10 percent of the building lot is rendered impervious.

- Farming, gardening, nursery, conservation, forestry, harvesting and spraying uses, provided that fertilizers, herbicides, pesticides, manure and other leachable materials are not stored outdoors. PROH IBITED USES

- Storage of liquid petroleum products of any kind except for storage is a free-standing container within a building of fuel for the heating of that building

- Storage of road salt or other deicing chemicals.

- Disposal of snow that contains deicing chemicals and that has been brought in from outside the District.

- Industrial uses that discharge process wastewater on site.

- Outdoor storage of fertilizers; herbicides and pesticides, and outdoor uncovered storage of manure.

- Animal feedlots.

- Mining of land except as incidental to a permitted use. 


\section{SPECIAL PERMIT USES}

- The application of pesticides for uses that are non-domestic and non-agricultural, provided that all necessary precautions shall be taken to prevent hazardous concentrations of pesticides in the water and on the land within the Groundwater Protection District as a result of such application, such precautions to include, but not be limited to erosion control techniques, the control of runoff water (or the use of pesticides having low solubility in water), the prevention of volatilization and redisposition of pesticides and the lateral displacement (ie-winddrift) of pesticides.

- The application of fertilizers for uses that are non-domestic and non-agricultural, provided that such application shall be made in such a manner as to minimize adverse impacts on surface water and groundwater due to nutrient transport and deposition or sedimentation.

The Conservation Law Foundation model ordinance further provides that the special permit application shall be reviewed by the board of health, planning board, conservation commission and engineer or department of public works. A public hearing is then held, and a special permit is issued based on recommend conditions and public hearing considerations. 34 
(4) North Kingstown Zoning Ordinance: Groundwater Overlay District

North Kingstown's existing groundwater protection ordinance consists of two overlay districts: the Groundwater Recharge Overlay District, and the Groundwater Reservoir Overlay District. The ordinance references the report Hydrologic Characteristics and Sustained Yield of Principal Groundwater Units, Potowomut-Wickford Area, Rhode Island in defining the boundaries of each overlay district. The Recharge Overlay District is described as land "upstream of any public well site and lying within the drainage basins of the Hunt, Annaquatucket and Pettasqumscutt Rivers and having a transmissivity greater than 0 gallons per àay per foot." The Reservoir Overlay District includes all lands in the town having a saturated thickness of over forty feet and a transmissivity greater than sixty thousand gallons per day. 35

Within the Groundwater Recharge Overlay District, permitted uses are those uses permitted in the primary (underlying) zoning district provided discharge of effluent into the ground meets the chemical standards of the U.S. Environmental Protection Agency (EPA). Other uses may be permitted only after "special exception" review provided that proof be submitted that the proposed use will not cause pollution. 36

The Groundwater Reservoir Overlay District in North Kingstown is more restrictive in its allowed uses in that 
land within its boundaries is considered the principal source of drinking water in the town.

Permitted uses are single family residential, recreation, conservation and agriculture, with specific reference to density allowance: (1) maximum lot coverage - twenty percent; (2) lot area - three acres, three hundred feet frontage; or (3) average density - one-third dwelling unit per acre. 37

COMPARISON OF REVIEWED ORDINANCES

Review of the four ordinances studied indicate that certain uses are recognized by different localities as being potentially hazardous to groundwater supplies and therefore should be closely regulated or prohibited. All of the ordinances reviewed have provisions requiring a "special" or "conditional" use permit for those potentially hazardous uses that may be permitted is pollution/hazard issues are properly addressed. The burden of proof lies with the applicant in all four of the ordinances.

The first three (3) model ordinances similarly prohibit certain land uses that, by their nature, result in pollutants seeping directly into the groundwater table. Instead of listing specific land uses that are prohibited, the North Kingstown Groundwater Recharge Overlay District relies on EPA standards to regulate effluent discharge, or requires the applicant to submit proof that no pollution will occur. North Kingstown does, however, specifically limit uses in 
the Groundwater Reservoir Overlay District to low density residential, recreation, conservation, and agriculture uses. Each of the four ordinances are similar in that they necessarily prohibit known hazardous uses, while maintaining flexibility for applicants to develop pollution controls for uses that are not detrimental if appropriate precautions are taken. 


\section{CHAPTER FIVE}

SUMMARY OF FINDINGS AND RECOMMENDATION

OF LOCAL ORDINANCE

The earlier chapters of this report explore the workings of groundwater resources and conditions related to the Hunt River groundwater aquifer. The Hunt River, dividing the towns of North Kingstown and East Greenwich, must be equally protected by both towns through land use regulations if groundwater quality is to be effectively preserved.

There is a need to manage development growth within the area of the Hunt River if important potable water supplies are to be sustained. Although general regulations on the state and federal level of government are helpful in addressing groundwater protection issues, local governments are best suited to apply restrictions/regulations on a sitespecific basis.

As referenced in chapter 3 , state legislation encourages local governments to develop groundwater protection ordinances. North kingstown has had a zoning ordinance to address groundwater protection for a number of years; East Greenwich is recently developing local use regulations to protect the valuable resource.

Review of existing and model ordinances indicates that, in developing an effective local ordinance for groundwater protection, certain land uses should be prohibited within aquifer recharge areas. Prohibited uses should be those 
uses that result in leachable pollutants, which cannot be reasonably prevented from seeping into groundwater supplies. When pollutants can be controlled through appropriate measures, such uses should be considered for allowance provided the proposed use is closely scrutinized and conditionally approved. To allow for flexibility in pollution control techniques, it is recommended that the land developer or applicant be given the "burden of proof" to assure that a proposed use will not be detrimental to groundwater supplies .

RECOMMENDATION OF LOCAL ORDINANCE

Reflecting on the model ordinances studies, herein is an ordinance suggested to be considered in whole or part for adoption by the towns of East Greenwich and/or North Kingstown.

TOWN OF ORDINANCE NO. 87-

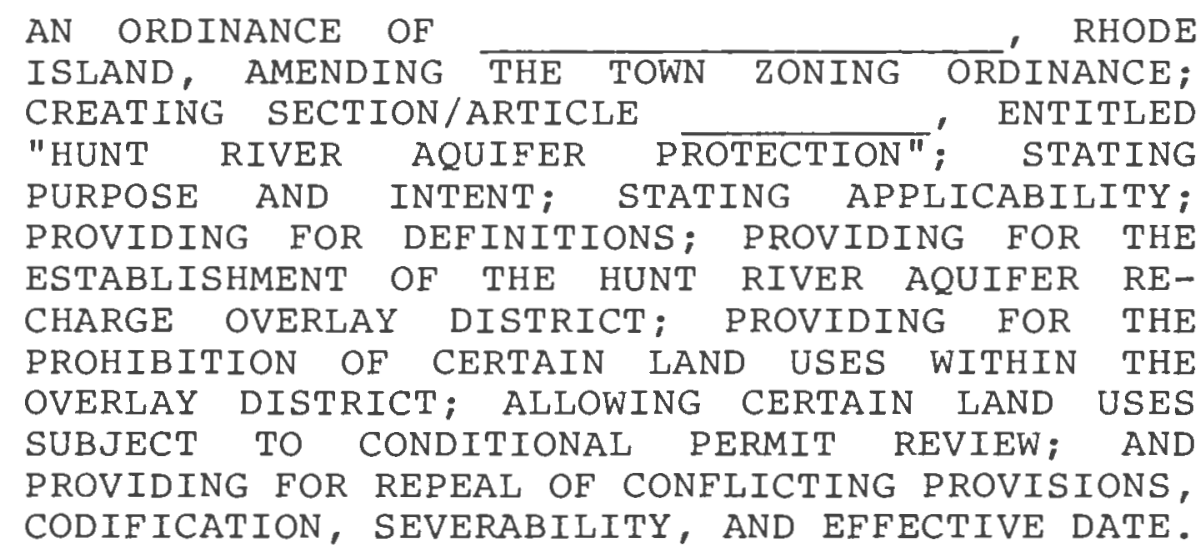


WHEREAS, the Hunt River and its associated groundwater aquifer is an important source of existing and future water supply, including drinking water; and

WHEREAS, accidental spills and discharges of petroleum products and other toxic and hazardous materials threaten the quality of groundwater aquifer supplies and related water resources in Rhode Island, posing potential public health and safety hazards and threaten economic loss to the citizens of the state and of the Town of ; and

WHEREAS, unless preventative measures are adopted to prohibit discharge of toxic and hazardous materials and to control their storage within the Town, further spills and discharges will predictably occur, and with greater frequency by reason of increased development in the Town of ; and

WHEREAS, findings set forth in the Water Quality Management Plan of Rhode Island prepared pursuant to section 288 of the Federal Clean water Act, support the need for local government protection of valuable groundwater resources;

NOW, THEREFORE, BE IT ORDAINED BY THE TOWN COUNCIL OF RHODE ISLAND, that:

\section{SECTION 1}

Section the zoning ordinance of the Town of is hereby amended by adding subsection , which is created as follows: 
Sec. - Hunt River Aquifer Protection.

(1) Purpose and Intent. It is the intent of this ordinance to promote and protect the public health, safety, and general welfare of the citizens of the Town of by regulating aspects of land development that would otherwise contribute to the degradation of the Hunt River aquifer potable groundwater supplies.

(2) Applicability. The regulations of this ordinance. shall apply to land development and land use occurring within the boundaries of the Hunt River Aquifer Recharge Overlay District (HRAROD) as defined in section (3)c; the HRAROD shall be considered as overlapping other zoning districts established in the Town of ._. No uses not permitted in the portions of the districts so overlain shall be permitted within the overlay district.

(3) Definitions and establishment of the Hunt River Aquifer Recharge Overlay District. For the purpose of this ordinance certain terms and words are defined as follows:

a. Aquifer: A geological formation that is capable of yielding a significant amount of groundwater to a well or spring, often characterized as loose (unconsolidated) surficial deposits underlined by a relatively impervious

$$
-46-
$$


layer such as clay or bedrock.

b. Transmissibility: A term used to measure an aquifer's ability to yield groundwater, a rate usually measured in gallons per day (gpd) per foot.

c. Hunt River Aquifer Recharge Overlay District (HRAROD) : an overlay district designating the primary groundwater recharge area for the Hunt River groundwater aquifer. The Recharge Overlay District includes land proximate to the Hunt River, depicted on Plate 2 of the U.S. Geological Survey Hydrologic Characteristics and sustained Yield of Principal Groundwater Units, Potowomut - Wickford Area, Rhode Island, as having a transmissibility of greater than zero gallons per day (GPD) per foot.

A map identifying the general boundaries of the Hunt River Aquifer Recharge overlay District shall be on file in the Town Planning Department. The delineation of the overlay District area may be revised by the Planning Board as the extent of the aquifer recharge area is more accurately defined.

Where the bounds as delineated are in doubt or in dispute, the burden of proof shall be upon the owner(s) of the land in question to show 
where they should properly be located. At the request of the owner(s), the Town may engage a professional geologist or soil scientist to determine more accurately the location and extent of the aquifer or recharge area, and may charge the owner(s) for all or part of the cost of the investigation.

(4) Use regulations: Within the Hunt River Aquifer Recharge Overlay District (HRAROD) land shall be subject to the following use restrictions, in addition to those of the underlying district:

a. Prohibited Uses: Within the HRAROD, the following uses are prohibited, unless they are established before the effective date of this ordinance and therefore are non-conforming (subject to the provisions of paragraph (4)c): Sanitary landfills, junkyards, municipal sewage treatment facilities with on-site disposal of primary or secondary treated effluent, car washes, road salt stockpiles, dry cleaning establishments, boat and motor vehicle service and repair, metal plating, chemical and bacteriological laboratories, and any other use which involves as a principal activity the manufacture, use, storage, transportation, or disposal of toxic or hazardous materials, except as allowed by special permit as provided for in paragraph (4)b of this section. 
b. Special Permit Uses: Within the HRAROD, the following uses shall be allowed only if granted a special permit by the planning board:

1. Transportation terminals.

2. Any principal use involving the sale, storage, or transportation of fuel oil or gasoline.

3. Any use involving the retention of less than $30 \%$ of the lot area in its natural state with no more than minor removal of existing trees and ground vegetation, or rendering impervious more than $10 \%$ of the lot area.

4. Any use involving on-site disposal of processed wastes from operations other than personal hygiene and food for residents, patrons, and/or employees.

5. Any use (other than a single-family dwelling) with a sewage flow exceeding 10 gallons per $1,000 \mathrm{sq}$. ft. of lot area or exceeding 15,000 gallons per day regardless of lot area.

6. Any use involving the generation of toxic or hazardous materials in quantities greater than associated with normal household use.

7. The mining of land except as incidental to a permitted use.

8. The spraying or spreading of chemical fertilizers or pesticides after approval by the U.S. Department of Agriculture, and the Soil 


\section{Conservation Service.}

9. Animal feedlot.

10. Cemetery.

c. Non-conforming uses: A non-conforming use may be continued and/or expanded by not more than a $25 \%$ increase in the original structure, floor space, bulk or size, or land area as existing at the effective date of this ordinance and may be replaced or repaired, with the approval of the planning board, if the Board believes that the continued or expanded use will not be more detrimental to the groundwater aquifer. A nonconforming use which has been discontinued for 18 months may not be resumed.

\section{SECTION 2}

\section{REPEAL OF CONFLICTING PROVISIONS}

All previous ordinances, resolutions, or motions of the Town Council of , Rhode Island which conflict with the provisions of this ordinance, are hereby repealed to the extent of such conflict. All special Acts of the legislature applying only to the Town of and which conflict with the provision of this ordinance are hereby repealed to the extent of such conflict. 
SECTION 3

\section{CODIFICATION}

The provisions of this ordinance shall be incorporated into the Town Code and the word "ordinance" may be changed to "section," "article," or other appropriate work, and the sections of this ordinance may be renumbered or relettered to accomplish such intentions.

SECTION 4

SEVERABILITY

If any sections, part of a sentence, paragraph, phrase or word of this ordinance is for any reason held to be unconstitutional, inoperative or void, such holdings shall not affect the remaining portions hereof and it shall be construed to have been the legislative intent to pass this ordinance without such unconstitutional, invalid or inoperative part.

SECTION 5

EFFECTIVE DATE

The provision of this ordinance shall become effective upon receipt from the Rhode Island secretary of state of official acknowledgement that this ordinance has been filed with the Department of state.

Approved and adopted by the Town council of Rhode Island, on this day of 19 
NOTES

1. Rhode Island Office of Statewide Planning, 208 Water Quality Plan for RI: Status of Recommendations (Providence: Rhode Island Office of Statewide Planning Program, 1982), P. 43 .

2. North Kingstown, North Kingstown Revised Zoning Ordinance (1978), sec. $17-8-6$ and 17-8-7.

3. Rhode Island Statewide Planning Program, Land Use and Groundwater Quality, South County, Rhode Island (Providence: Rhode Island Statewide Planning Program, 1981), p. 4 .

4. Massachusetts Audubon Society Community Groundwater Protection Project, An Introduction to Groundwater and Aquifers, Groundwater Information Flyer Series, no. 1 (Lincoln: Massachusetts Audubon Society, 1983), p. 4.

5. Ibid., p. 11 .

6. Ibid.

7. William B. Allen, Joseph B. Gonthier, and J.S. Rosenshein, Hydrologic Characteristics and sustained Yield of Principal Groundwater Units, Potowomut-Wickford Area, Rhode Island (Washington, D.C.: United States Government Printing office, 1968), p.10.

8. Rhode Island Statewide Planning Program, Land Use and Groundwater Quality, p. 6 .

9. Ibid., p. 7 .

10. Municipal Finance Officers Association, Environmental Finance 2 (Winter 1982): 1 .

11. Rhode Island Statewide Planning Program, Land Use and Groundwater Quality, p. 4 .

12. Allen, Gonthier, and Rosenshein, Potowomut-Wickford Area, plate 2 .

13. Soil Conservation Service, Soil Survey of Rhode Island (Washington, D.C.: U.S. Department of Agriculture, $1981)$, p. 51 .

14. Rhode Island Statewide Planning Program, Land Use and Groundwater Quality, p. 48 . 
15. Rhode Island Office of Statewide Planning, 208 water Quality Plan, p. 44 .

16. Rhode Island Statewide Planning Program, Land Use and Groundwater Quality, p. 49.

17. Ibid.

18. Ibid.

19. Ibid., p. 50 .

20. Ibid., p. 51 .

21. Ibid.

22. Rhode Island, Hazardous Water Management Act, 23-46.2$4(d)$.

23. Rhode Island Statewide Planning Program, Land Use and Groundwater Quality, p. 53.

24. American Planning Association, Land Use Law \& Zoning Digest 38 (July 1986):26.

25. Rhode Island, Zoning Enabling Act, 45-24-3.

26. Rhode Island Office of Statewide Planning, 208 Water Quality Plan, p. 48 .

27. Rhode Island, Hazardous Waste Management Act, as amended, 23-46.2-10.1.

28. Craig Ten Broeck et al., Model Land Use Ordinances for the Ten Town 208 Area (Auburn: Androscoggin Valley Regional Planning Commission, 1977), pp. I-1 - VIII-6.

29. Ibid., p. I-I.

30. Ibid., p. I-3.

31. Mark Bobrowski and John R. Hughes, The Handbook For Rhode Island Conservation Commissioners (Wakefield: Rhode Island Projects for the Environment, Inc., 1983), pp. 1-107.

32. Ibid., p. 99.

33. Conservation Law Foundation of New England, Inc., Underground Petroleum Storage Tanks: Local Regulation of a Groundwater Hazard (Boston: Conservation Law Foundation of New England, Inc., 1984), p. 93. 
34. Ibid., p. 94 .

35. North Kingstown Revised Zoning Ordinance, sec. 17-8-7.

36. Ibid.

37. Ibid. 


\section{BIBLIOGRAPHY}

Ahmed, Riaz. A Manual for Assessment of Nonpoint Sources of Water Pollution. Hartford, CT: The Center for the Environment and Man, Inc., April 1979.

Allen, William B. Groundwater Resources of the East Greenwich Quadrangle, Rhode Island. Geological Bulletin No. 8. Providence: Rhode Island Development Council, 1956.

Allen, William B.; Gonthier, Joseph B.; and Resenshein, J.S. Hydrologic Characteristics and sustained Yield of Principal Groundwater Units, Potowomut-Wickford Area, Rhode Island. Geological Survey Water-Supply Paper 1775. Washington, D.C.: United States Government Printing office, 1968.

American Planning Association. Land Use Law \& Zoning Digest 38 (July 1986): 1-28.

Bobrowski, Mark and Hughes, John R. The Handbook for Rhode Island Conservation Commissioners. Wakefield: Rhode Island Projects for the Environment, Inc., 1983.

Broeck, Craig Ten; Attig, J.; Lea, F.; Lynch, R.; Thompson, $B ;$ and Vachon, $J$. Model Land Use Ordinances for the Ten Town 208 Area. Auburn: Androscoggin Valley Regional Planning Commission, 1977.

Brooks, Richard Oliver. Municipal Environmental Ordinances. 2 vols. Kingston, RI: University of Rhode Island, Graduate Curriculum of Community Planning and Area Development, 19

Conservation Law Foundation of New England, Inc. Underground Petroleum Storage Tanks: Local Regulation of a Groundwater Hazard. Boston: Conservation Law Foundation of New England, Inc., 1984.

Dee, Norbert et al. "An Environmental Evaluation System for water Resource Planning." Water Resource Research 9:3 $(1973): 523-535$.

DiNovo, Frank. "Local Groundwater Protection Programs." PAS Memo; American Planning Association (August 1983) : 1-4.

DiNovo, Frank, and Jaffe, Martin. "A Survey of Local Regulations for Groundwater Protection." Paper presented at the 4 th Annual Zoning Institute meeting, New York, NY, September 1984. 
Economic Commission for. Asia and the Far East. The Development of Groundwater Resources with special Reference to Deltaic Areas. Water Resources Series No. 24. New York: United Nations, 1963.

Ertel, Madge 0 . The Role of Citizen Advisory Groups in water Resources Planning. Amherst, MA: water Resources Research Center, University of Massachusetts, August 1974 .

Government Finance Research Center - Municipal Finance officers Association. Environmental Finance 2:1 (Winter $1982): 1-8$.

Greenberg, E.; Meyland, S.; and Tripp, J. Watershed Planning for the Protection of Lang Island's Groundwater. NY: Coalition for the Protection of Long Island's Groundwater, 1982 .

Healy, Robert G., and Rosenberg, John S. Land Use and the States. Baltimore, MD: The Johns Hopkins, University Press, 1979.

Jeffery, Arthur D. Economics of Water Supply in Rhode Island. Miscellaneous Publication 62. Kingston: University of Rhode Island Agricultural Experiment Station, July 1966.

Koch, Stuart G. Water Resources Planning In New England. Hanover, $\mathrm{NH}$ : University Press of New England, 1980.

Kupa, John and Whitman, William. The Forest and Wetland Vegetation Types of Rhode Island. Kingston: University of Rhode Island Department of Forestry, Agricultural Experiment Station, 196 (Vegetation types determined from 1962 Air Photos, superimposed on U.S.G.S. Quadrangle Maps).

Lang, S.M. Appraisal of the Ground-Water Reservoir Areas in Rhode Island. Geological Bulletin No. 11. Providence: Rhode Island water Resources Coordinating Board, 1961.

Lang, Solomon M.; Bierschenk, William H.; and Allen, William B. Hydraulic Characteristics of Glacial Outwash in Rhode Island. Hydrologic Bulletin No. 3. Providence: Rhode Island water Resources Coordinating Board, 1960.

Massachusetts Audubon Society Community Groundwater Protection Project. An Introduction to Groundwater and Aguifers. Groundwater Information Flyer Series, no. 1. Lincoln: Massachusetts Audubon Society, 1983.

McHarg, Ian L. Design with Nature. Garden City, NY: Doubleday and Company, Inc., 1971. 
Nelson, Ron. "Level B Water Resources Planning in an Urban Setting." Water Resources Bulletin II (1975): 605-12.

North Kingstown, R.I. North Kingstown Revised Zoning ordinance (1978).

Organization for Economic Co-operation and Development. Water Management in Industrialized River Basins. Paris: OECD, 1980 .

Pereira, H.C. Land Use and Water Resources in Temperate and Tropical Climates. New York: Cambridge University Press, 1973.

Rhode Island. Hazardous Waste Management Act. Statutes (1981).

Rhode Island. Zoning Enabling Act. Statutes (19__).

Rhode Island Office of Statewide Planning. 208 Water Quality Management Plan for RI: Status of Recommendations. Report No. 43. Providence: RI Office of statewide Planning, November 1982 .

Rhode Island Statewide Planning Program. Land Use and Groundwater Quality, South County, Rhode Island. Technical Paper No. 98. Providence: Rhode Island Statewide Planning Program, September 1981.

Rosen, Sherman T. Manual for Environmental Impact Evaluation. Englewood Cliffs, NJ: Prentice Hall, Inc., 1976.

Sewell, G. Environmental Quality Management. Englewood Cliffs, NJ: Prentice Hall, Inc., 1976.

Soil Conservation Service. Soil Survey of Rhode Island. Washington, D.C.: US Department of Agriculture, 1981.

Tourbier, J. Toby, and Westmacott, Richard. Water Resources Protection Technology: A Handbook of Measures to Protect Water Resources in Land Development. Washington, D.C.: The Urban Land Institute, 1981.

Tripp, J., and Jaffe, Martin. "Preventing Groundwater Pollution: Towards a Coordinated strategy to Protect Critical Recharge Areas." Harvard Environmental Law Review 3 (1979); 1,9.

U.S. Environmental Protection Agency. Planning Workshops to Develop Recommendations for a Ground water Protection Strategy. Washington, D.C.: U.S. Environmental Protection Agency, June 1980. 
Warner, Katherine P. Public Participation in water Resources planning. Arlington, VA: National Water Commission, July 1971. 